\title{
The perception of corporate social responsibility and its impact on consumer buying behaviour in the process of globalization
}

\author{
Margareta Nadanyiova ${ }^{1, *}$ \\ ${ }^{1}$ University of Zilina, Faculty of Operation and Economics of Transport and Communications, \\ Department of Economics, Univerzitna 1, 01026 Zilina, Slovak Republic
}

\begin{abstract}
.
Research background: In the current era of globalization, corporate social responsibility has been gaining an increasing attention. By implementation CSR activities into their business strategy, companies can gain positive feedback from stakeholders including consumers and thus new competitive advantage. Creating positive attitude on CSR from the consumers that subsequently can influence their buying behaviour depends on many factors such as how the companies understand and perform their CSR initiatives and finally, how they communicate them to stakeholders.

Purpose of the article: The main aim of the article is to determine the perception of corporate social responsibility and its impact on consumer buying behaviour in the process of globalization. This includes the literature review on the issue and analysis focused on the perception of corporate social responsibility and its impact on consumer buying behaviour.

Methods: General scientific methods were applied for the processing of the data as well as mathematical-statistical methods to evaluate the data collated from the results of the questionnaire survey and to statistical hypothesis testing. The secondary data for the analysis were obtained from scientific researches, statistical tables and professional publications. In order to determine the perception of corporate social responsibility and its impact on consumer buying behaviour, a questionnaire survey was conducted among Slovak consumers.

Findings \& Value added: Based on analysis and questionnaire survey results, measures for the efficient implementation of corporate social responsibility are proposed, and its benefits are highlighted, such as strengthening the company's image, improving customer relationships, gaining their loyalty and competitive advantage.
\end{abstract}

Keywords: corporate social responsibility; consumer buying behaviour; stakeholders; globalization; sustainability;

JEL Classification: $M 14 ; Q 01 ; Q 56 ; F 60$;

\footnotetext{
*Corresponding author: margareta.nadanyiova@,fpedas.uniza.sk
} 


\section{Introduction}

In recent decades, the global development of society has undergone changes, which many scholars describe as the process of globalization. It is an uncontrolled process in which the countries of the world are increasingly integrated into a single global system, with states converging within a cultural, economic, social or political sphere. There is an increasing development of information technologies and mass dissemination of information $[1,2]$. During the process of globalization, the economic area has become increasingly dependent on individual subjects of the world economy and markets, there has been an increased movement of capital, services or technology [3]. The main actors in the global economy are multinational corporations, states, and last but not least, integration groups and international organizations. And just the multinational corporations, i.e. large private companies are the ones whose operations extend beyond the borders of their home state. They have strengthened their position in the process of globalization and currently significantly influence the economic development of both national and integrating economic entities and the world economy.

The question, therefore, arises as to what extent these companies could or even should be interested in the public interest and contribute to solving global and local problems. At this point, corporate social responsibility (CSR) comes into play, which can become a tool to support the sustainable growth of the local economy, as well as society as a whole. However, the issue of CSR is far from being an issue for multinational companies, but for all companies, regardless of their scope, subject of business or size [4].

CSR is not just an ideology or an ethical or moral fulfillment of the company's mission or expectations from the company [5,6]. It is mainly an economic necessity of the company's survival in a competitive environment. Many scientific researches are devoted to the general concept of CSR, its benefits, strategic aspects, implementation and use of this concept in practice. However, fewer resources are devoted to CSR issues from the perspective of consumers and customers, e.g. how CSR affects customers' purchasing decisions. And it is precisely the customers who make a profit for the company, who have a direct impact on the success of the company and who should determine the direction in which the company is heading. They do this through their preferences in buying behaviour [7]. CSR can thus become a tool for the company to differentiate itself, but also a competitive advantage [8].

\section{Literature Review}

The company's values, social ethics and corporate social responsibility are connected with the culture of the company and its management $[9,10]$. There are two views on the company's responsibilities in society. The first, neoclassical, is of the opinion that making a profit within the limits of the law is the main and only duty of the company [11]. The second view puts the company's responsibilities in a broader context. The basic idea of this opposite is that the responsibility of companies is more than just making a profit. On the other hand, it is not entirely clear what exactly is meant by this higher broader form of responsibility. Although many companies have always tried to do business responsibly, it was not until the second half of the 20th century that the concept of CSR appeared [12].

However, there is still no uniform definition that accurately describes the meaning of the term. According to Coombs \& Holladay, the reason why it is difficult to define CSR is that it is not reducible to one simple concept. In the past, when marketing researchers discussed CSR-related aspects within their discipline, they initially focused on expanding marketing concepts before analyzing corporate social functions. Currently, the research is focused on strategic ways of application, which in most cases focused only on the main stakeholders consumers and the use of related distribution channels [13]. 
The concept of social responsibility was first mentioned by Bowen, who defined CSR as the obligations of businessmen to pursue those policies, to make those decisions, or to follow those lines of action which are desirable in terms of the objectives and values of our society [14].

The basis for the modern definition of social responsibility can be also found in Carroll's theory, according to which CSR consists of four levels - economic, legal, ethical and philanthropic. Carroll's theory is often presented as one of the best-known models of CSR, that demonstrates the relative importance of economic, legal, ethical, and philanthropic responsibilities [15].

CSR can be defining as a company's commitment to contributing to sustainable development, a way of treating employees, their families, the local community and society in general to improve their quality of life [16]. Another view of CSR claims that it includes minimizing the negative externalities caused by its activities and maximizing its positive impact on society [17]. Similarly, Bussard et al. explain CSR as a set of management practices that ensure an organization minimizes the negative while maximizing the positive consequences of its behaviour on society [18].

According to Putnova, CSR represents such behaviour of companies, where they take into account the needs of their internal and external environment, in general to help the overall improvement of society beyond their commercial activities [19].

European Commission defines CSR as a concept whereby the company integrates social and environmental concerns in their business operations and in their interactions with their stakeholders on a voluntary basis [20]. The principle of volunteering also highlighted many other scholars, e.g. in relation to the integration of social and environmental aspects into the company's daily business operations and interaction with stakeholders [21].

Regarding the perception of CSR by consumers, some authors $[16,22]$ point out that a particular company's product preference is linked to the extent to which the company's ethical behaviour exceeds customer expectations. On the other hand, Sen and Bhattacharya conclude that the consumer's response to social responsibility is conditioned by his agreement or identification with the company [23]. However, the impact on the consumer buying behaviour may be smaller when CSR will be at the expense of product quality. For example, Auger et al. found in his research that while consumers had no problem listing the functional properties of the products they had just bought, only a small percentage of them were able to recall at least the basic ethical characteristics of the same products [24].

As a result, customers lack knowledge of companies' CSR activities. Mohr et al. attributes this to inefficient communication of CSR activities by companies [17]. Although consumer awareness of CSR appears to be very low, customers are actually interested in it and would like to know more about CSR. Which is an opportunity for companies to communicate CSR to customers and create a good image [25].

Awareness of customers about the company's activities is a condition for it to be possible to evoke an attitude towards the company and thus influence consumer buying behaviour [26]. The same awareness is influenced by CSR activities, but at the same time it is necessary for customers to know about these activities. Therefore, when examining shopping behaviour, it is necessary to first start by examining customers' awareness of CSR activities. Although corporate social responsibility is able to evoke a positive perception of customers on a theoretical level, there is no enough evidence of its effectiveness in the market in purchasing decisions.

\section{Methods}

The main aim of the article is to determine the perception of corporate social responsibility and its impact on consumers buying behaviour in the process of globalization. This includes 
the literature review on the issue and analysis focused on the perception of corporate social responsibility and its impact on consumer buying behaviour. The secondary data for the analysis were obtained from scientific researches, statistical tables and professional publications. In order to determine the perception of corporate social responsibility and its impact on consumer buying behaviour, a questionnaire survey was conducted among Slovak consumers. Based on analysis and questionnaire survey results, measures for the efficient implementation of corporate social responsibility are proposed, and its benefits are highlighted, such as strengthening the company's image, improving customer relationships, gaining their loyalty and competitive advantage.

General scientific methods were applied for the processing of the data as well as mathematical-statistical methods to evaluate the data collated from the results of the questionnaire survey and to statistical hypothesis testing.

The aim of questionnaire survey was to determine the perception of corporate social responsibility and its impact on consumer buying behaviour in Slovak conditions. For determination the sample size, the base file representing number of population older than 15 was obtained from demographic statistics of the Statistical Office of the Slovak Republic. The confidence interval was set at 5\%, with a confidence level of $95 \%$. This means that for the questionnaire survey a $5 \%$ margin of error is assumed. The sample size calculated by the calculator was determined to be 384 respondents. The actual number of respondents participated in the questionnaire survey was 532. The time required for the survey was 3 months (January - March 2020). The survey took the form of questionnaire method through e-mail communication. For the processing of the survey data, the quantitative assessment method was applied.

The questionnaire was formed of three parts. The first part was focused on the general socio-demographic profile of respondents. The second one was devoted to determine the perception of corporate social responsibility by Slovak consumers. The last part dealt with the impact on consumer buying behaviour in Slovak conditions.

In order to achieve the main aim of the article, based on the theoretical background and survey results, research hypotheses are formulated:

- Hypothesis 1: More than 50\% Slovak consumers know the concept of CSR.

- Hypothesis 2: More than 50\% Slovak consumers consider the use of CSR in the company to be a factor of strengthening the company's image.

- Hypothesis 3: When making purchasing decisions, 50\% Slovak consumers prefer products of the socially responsible company.

The marginal rate $50 \%$ was set as the expression of the simple majority [27].

Statistical hypotheses testing is defined as a statement of the assumption of unknown parameters in the basic set, which is formulated as a statistical hypothesis and its validity is verified by statistical procedures based on selection characteristics. The role of statistical hypotheses testing is to decide whether to accept or reject the hypothesis regarding the basic set in accordance to the information from the available choice. In verification of the hypotheses, the methodology of statistical hypothesis testing consisting of the following steps was met [28]:

1. Formulation of the null hypothesis $\left(\mathrm{H}_{0}\right)$.

2. Formulation of the alternative hypothesis $\left(\mathrm{H}_{1}\right)$.

3. Determining the level of significance $(\alpha)$.

4. Calculation of test statistics and probability.

5. Decision.

The test statistic for hypotheses $1-3$ we calculated by using the method testing a single proportion by one- tailed testing because it is commonly used [29, 30]. Significance level $\alpha$ was determined at 0.05 . 


\section{Results}

\subsection{Results of questionnaire survey focused on the perception of corporate social responsibility and its impact on consumer buying behaviour in Slovak conditions}

Of the 532 respondents in the sample set, $349(66 \%)$ were female and $183(34 \%)$ male. On the basis of consumer age classification, $105(20 \%)$ respondents were aged 15-24; $112(21 \%)$ respondents were aged 25-34; $115(22 \%)$ respondents were aged 35-44; 109 (20\%) respondents were aged 45-54; 67 (13\%) respondents were aged 55-64; 24 (4\%) respondents were aged 65 and more.

The results of the questionnaire survey show that $76 \%$ respondents know the CSR concept. $71 \%$ respondents consider the implementation of corporate social responsibility as a necessary part of company's business strategy. According respondents, the greatest benefits of implementation CSR in companies include strengthening the company's image (68\%), improving customer relationships (52\%), gaining customer loyalty (41\%) and increasing competitive advantage (39\%). As the most important area of CSR, most of the respondents $(57 \%)$ indicate the environmental responsibility, next it is the social responsibility (33\%) and the least important area is the economic responsibility (10\%). As the most important activities in environmental responsibility, respondents indicate eco-friendly behaviour (76\%), the social responsibility includes employee care and their safety $(62 \%$; and in economic responsibility, respondents consider making profit in an honest and ethical manner (69\%).

The results of the questionnaire survey show that when making purchasing decisions, $52 \%$ of Slovak consumers prefer products of the socially responsible company, especially products such as food, cosmetics, drugstore, cloths and some services (banking services, telecommunication services and transport services).

\subsection{Verification of statistical hypotheses}

To verify the statistical hypotheses $1-3$, we used the method testing a single proportion. Results of verification these statistical hypotheses are shown in Table 1.

Significance level $\alpha$ was determined at 0.05 . The test criteria were calculated according to:

$$
T=\frac{p-\pi_{0}}{\sqrt{\frac{\pi_{0} *\left(1-\pi_{0}\right)}{n}}}
$$

By using the tables of the normalized normal distribution, we find the critical value for the right-tailed test (2) for hypothesis 1 and 2, the left-tailed test (3) in the case of hypothesis 3 .

$$
\begin{gathered}
T>Z_{2 \alpha} \\
T<-Z_{2 \alpha}
\end{gathered}
$$


Table 1. Verification of statistical hypotheses

\begin{tabular}{|c|c|c|c|c|c|}
\hline $\begin{array}{l}\text { Calculation of } \\
\text { the sample } \\
\text { proportion: } \\
\qquad p=\frac{m}{n}\end{array}$ & $\begin{array}{c}\begin{array}{c}\text { Satisfaction of the } \\
\text { condition }\end{array} \\
\boldsymbol{n} * \boldsymbol{\pi}_{\mathbf{0}} *\left(\mathbf{1}-\boldsymbol{\pi}_{\mathbf{0}}\right)>\mathbf{5}\end{array}$ & $\begin{array}{c}\text { Test } \\
\text { criteria }\end{array}$ & $\begin{array}{l}\text { Critical } \\
\text { field }\end{array}$ & Inequality & $\begin{array}{c}\text { Acceptance } \\
\text { or rejection } \\
\text { of the } \\
\text { hypothesis }\end{array}$ \\
\hline \multicolumn{6}{|c|}{$\begin{array}{l}\text { Hypothesis 1: } \\
\mathrm{H}_{0}: 50 \% \text { Slovak consumers know the concept of CSR. }\end{array}$} \\
\hline $\mathrm{p}=0.76$ & $133>5$ & 11.994 & 1.645 & $11.994>1.645$ & $\mathrm{H}_{0}$ rejected \\
\hline \multicolumn{6}{|c|}{$\begin{array}{l}\text { Hypothesis 2: } \\
\mathrm{H}_{0}: 50 \% \text { Slovak consumers consider the use of CSR in the company to be a factor of strengthening } \\
\text { the company's image. } \\
\mathrm{H}_{1} \text { : More than } 50 \% \text { Slovak consumers consider the use of CSR in the company to be a factor of } \\
\text { strengthening the company's image. }\end{array}$} \\
\hline$p=0.68$ & $133>5$ & 8.303 & 1.645 & $8.303>1.645$ & $\mathrm{H}_{0}$ rejected \\
\hline \multicolumn{6}{|c|}{$\begin{array}{l}\text { Hypothesis 3: } \\
\mathrm{H}_{0} \text { : When making purchasing decisions, } 50 \% \text { Slovak consumers prefer products of the socially } \\
\text { responsible company. } \\
\mathrm{H}_{1} \text { : When making purchasing decisions, less than } 50 \% \text { Slovak consumers prefer products of the } \\
\text { socially responsible company. }\end{array}$} \\
\hline $\mathrm{p}=0.52$ & $133>5$ & 0.923 & -1.645 & $0.923<-1.645$ & $\mathrm{H}_{0}$ accepted \\
\hline
\end{tabular}

Source: Own processing.

Table 1 shows, that in hypotheses 1 and 2 the inequality applies, so we reject the hypothesis $\mathrm{H}_{0}$, i.e. accept the alternative hypothesis $\mathrm{H}_{1}$. In the case of hypothesis 3 , the inequality does not apply, so we do not reject the hypothesis $\mathrm{H}_{0}$, we accept it.

\section{Discussion}

Based on the analysis and survey results, it is obvious, that the majority of Slovak consumers know the concept of CSR. They are aware of benefits which result from the implementation of CSR for companies, and thus most of them consider the use of CSR in the company to be a factor of strengthening the company's image.

Some of the previous researches focused on the perception of CSR by consumers underestimate the impact of CSR on consumer buying behaviour and claim that the impact on the consumer buying behaviour may be smaller when CSR will be at the expense of product quality [23, 24]. In contrary, our results show, that when making purchasing decisions, 50\% Slovak consumers prefer products of the socially responsible company, especially in the case of food, cosmetics, drugstore, cloths and some services (banking services, telecommunication services and transport services). The disputed universal applicability and deviations of these survey results is linked to the fact that, although globalization has led to a radical increase in the degree of interdependence of national economies, it is necessary to accept the regional socio-cultural specificities of the market. This is because differences arise between nations due to different cultures, but also sociopolitical events in a given country or in the context of wider regional groupings.

However, In Slovakia, there are still many consumers who do not know which company is socially responsible, and which is not, they do not know which product is socially responsible and which is not, they do not have enough information about the CSR concept, CSR of particular companies and their activities and projects. In this reason, the number of such consumers could increase due to the effective communication focused on improving the 
awareness of customers about the company's socially responsible activities that could evoke a positive attitude towards the company and thus influence consumer buying behaviour.

\section{Conclusions}

The high importance of corporate social responsibility in the process of globalization brings an important task for the whole company, for tits management determining the long-term strategy, and also for its marketers. At the same time, however, this situation also brings opportunities. Extra steps towards increased social responsibility and sustainability can be a unique source of competitive advantage for a company. If this competitive advantage is closely linked to the company, its activities and image, it brings long-term benefits not only for the company, but also for the whole society. Social responsibility activities can become one of the subjects of marketing communication. These activities can represent the added value of a product or service, which can be a crucial factor in the purchasing decisions of consumers who are not indifferent to social responsibility. If a company manages to embed the principles of social responsibility deep into its strategy, it can build the image of a responsible company that will be closer to consumers. However, it is essential to maintain the consumer's confidence. Despite the fact that the use of corporate social responsibility activities for marketing purposes can bring great benefits to the company, especially when targeting the younger generations, it is important to maintain authenticity. The loss of trust on the part of customers can damage this built-up image in the long run.

Based on the analysis and survey results, the most visible benefits of efficient implementation of CSR include strengthening the company's image, improving customer relationships, gaining their loyalty and competitive advantage.

It follows from the above, that the issue of corporate social responsibility and its impact on consumer buying behaviour in the process of globalization has the great potential for the further research. It would be appropriate to examine and compare the impact of corporate social responsibility on consumer buying behaviour from the aspect of generational stratification.

This paper is a partial output of the project VEGA no. 1/0064/20: Behaviorism in a socially responsible communication strategy of enterprises.

\section{References}

1. Poliak, M., Krizanova, A., Semanova, S. (2014). The influence of contract form choice of the transport services ensuring on performance contracting entity requirement. Transport Problems, 9(4), 153-161.

2. Jurkovic, M., Kalina, T., Illes, L., Gajarsky, M. (2018). Identification of user requirements for ship simulators. In T. Kliestik (Eds.), 18th International Scientific Conference on Globalization and its Socio-Economic Consequences (pp. 2114-2119). Zilina: University of Zilina.

3. Kramarova, K., Valaskova, K. (2015). Globalization and transfer pricing: brief analysis of the legislation in the Slovak Republic. In. T. Kliestik (Eds.) 15th International Scientific Conference on Globalization and its Socio-Economic Consequences (pp. 353361). Zilina: University of Zilina.

4. Reicher, Z.R. (2019). Opportunities for small and medium sized enterprises in the field of corporate social responsibility, Ekonomicko-manazerske Spektrum, 13(1), 26-37.

5. Kliestikova, J., Krizanova, A., Corejova, T., Kral, P., Spuchlakova, E. (2018). Subsidies to Increase Remote Pollution? Science and Engineering Ethics, 24(2), 755-767. 
6. Nedeliakova, E., Hudakova, M., Masar, M., Lizbetinova, L., Stasiak-Betlejewska, R., Sulko, P. (2020). Sustainability of Railway Undertaking Services with Lean Philosophy in Risk Management-Case Study. Sustainability, 12(13), 5298.

7. Stuchly, J., Jambal, T., Lizbetinova, L. (2018). Loyalty Programs and Customer Preferences. In K. S: Soliman (Eds.) 32nd Conference of the International-BusinessInformation-Management-Association (IBIMA) (pp. 8321-8328). Norristown: IBIMA

8. Moravcikova, D., Krizanova, A., Kliestikova, A., Rypakova, M. (2017). Green Marketing as the Source of the Competitive Advantage of the Business. Sustainability, 9(12), 2218.

9. Krizanova, A., Majerova, J. (2013). The proposal of activities of pricing policy in the process of building and managing brand value in Slovak Republic. In L. Zhang, X. Li, \& J. Chen (Eds.), International Conference on Information, Business and Education Technology (ICIBET) (pp. 416-419). Paris: Atlatis Press.

10. Kliestikova, J., Janoskova, K. (2017). Branding with understanding: how national profile of consumer influences brand value perception. Marketing and management of innovations, 3, 149-157.

11. Majerova, J., Kliestik, T. (2015). Brand valuation as an immanent component of brand value building and managing. Procedia Economics and Finance, 26, 546-552.

12. Business Leaders Forum. (2012). Co je CSR. http://www.csr-online.cz/co-je-csr/

13. Coombs, W.T., Holladay, S. J. (2012). Managing corporate social responsibility: A communication approach. Malden, MA: Wiley-Blackwell.

14. Bowen, H.R. (1953). Social Responsibilities of the Businessman. Iowa City: University of Iowa Press, Iowa.

15. Carroll, A.B. (1979). A three-dimensional conceptual model of corporate performance, Academy of management review, 4(4), 497-505.

16. Pomering, A., Dolnicar, S. (2009). Assessing the Prerequisite of Successful CSR Implementation: Are Consumers Aware of CSR Initiatives? Journal of Business Ethics, 85, 285-301.

17. Mohr, L.A., Webb, D.J., Harris, K.E. (2001). Do Consumers Expect Companies to be Socially Responsible? The Impact of Corporate Social Responsibility on Buying Behavior. Journal of Consumer Affairs, 35(1), 45-72.

18. Bussard, A. et al. (2005). Corporate social responsibility. Overview of basic principles and examples. Bratislava: Integra Foundation.

19. Putnova, A. (2004). Sociální odpovědnost a etika podnikání. Brno: Akademické nakladatelstv CERM.

20. European Commission. (2020). Green paper and related documents. https://ec.europa.eu/environment/ipp /2001developments.htm

21. Chen, E., Gavious, I. (2015). Does CSR have Different Value Implications for Different Shareholders? Finance Research Letters, 14, 29-35.

22. Becker-Olsen, K.H., Cudmore, B.A., Hill, R.P. (2006). The Impact of Perceived Corporate Social Responsibility on Consumer Behavior. Journal of Business Research, 59(1), 46-53.

23. Sen, S. Bhattacharya, C.B. (2001). Does doing good always lead to doing better? Consumer reactions to corporate social responsibility. Journal of Marketing Research, 38(2), 225-243.

24. Auger, P., Burke, P., Devinney, T.M., Louviere, J.J. (2003). What Will Consumers Pay for Social Product Features? Journal of Business Ethics, 42(3), 281-304.

25. Hitka, M., Pajtinkova-Bartakova, G., Lorincova, S. Palus, H., Pinak, A., Lipoldova, M., Krahulcova, M., Slastanova, N., Gubiniova, K., Klaric, K. (2019). Sustainability in marketing through customer relationship management in a telecommunication company. Marketing and Management of Innovations, 4, 194-215. 
26. Majerova, J. (2014). Analysis of Specifics in Buying Behavior of Slovak Customers in Internet Environment. In L. Lee (Eds.) 2nd International Conference on Social Sciences Research (SSR 2014) (pp. 172-178). Singapore: Singapore Management \& Sports Scientific Institute.

27. Macfie, B.P., Nufrio, P.M. (2006). Applied Statistics for Public Policy. New York: M. E. Sharpe.

28. Rimarcik, M. (2007). Štatistika Pre Prax. Kosice: Marian Rimarcik.

29. Ruxton, G.D., Neuhauser, M. (2010). When should we use one-tailed hypothesis testing? Methods in Ecology and Evolution, 1, 114-117.

30. Lombardi, C.M., Hurlbert, S.H. (2009). Misprescription and misuse of one-tailed tests. Australian Ecology, 34, 447-468. 